\title{
Geological, Alteration and Mineralization Characteristics of Ali Javad Porphyry Cu-Au Deposit, Arasbaran Zone, NW Iran
}

\author{
Behzad Hajalilou*, Mehraj Aghazadeh \\ Department of Geology, Payame Noor University, Iran \\ Email: "hajalilou@pnu.ac.ir
}

Received 17 June 2016; accepted 19 August 2016; published 22 August 2016

Copyright (C) 2016 by authors and Scientific Research Publishing Inc.

This work is licensed under the Creative Commons Attribution International License (CC BY). http://creativecommons.org/licenses/by/4.0/

(c) (i) Open Access

\begin{abstract}
Ali Javad porphyry Cu-Au deposit is located $20 \mathrm{Km}$ north of Ahar city in Arasbaran metallogenic zone which is considered as a part of Alp-Himalayan mineralization belt. Magmatism in this area began in Late Cretaceous, followed by extensive magmatism in Cenozoic and Quaternary periods. Porphyry type mineralization developed in Ali Javad quartz monzonitic porphyry stock and Eocene pyroclastic and volcanic country rocks. Ali Javad porphyry intrusion has shoshonitic nature and shows characteristics of volcanic arc granitoids that it is have been emplaced in a post-collision tectonic setting. Alteration zones at the deposit demonstrated zoning which is comparable with Lowel-Guilbert model proposed for quartz-monzonite type porphyry copper deposits. Phyllic, argillic, silicic and propylitic alteration zones were observed at the surface while potassic alteration zone could be observed at depth in drill core samples. Mineralization was recognized both as supergene and hypogene, the latter was as veins, veinlets and disseminations. Dominant hypogene minerals were chalcopyrite, bornite, molybdenite, pyrite and magnetite while chalcocite, covellite and limonite were dominant supergene minerals. Four mineralization zones were observed in the deposit as leached, transitional, supergene and hypogene zones. Average grades were $0.75 \%$ for copper and $1.86 \mathrm{ppm}$ for gold with $81.5 \mathrm{Mt}$ proved reserve for copper and $37.8 \mathrm{Mt}$ for gold.
\end{abstract}

\section{Keywords}

Geology, Alteration, Mineralization, Ali Javad Porphyry Cu-Au Deposit, Iran

\section{Introduction}

Porphyry deposits are major world reserves for copper and molybdenum and are exploited also for their gold, ${ }^{*}$ Corresponding author.

How to cite this paper: Hajalilou, B. and Aghazadeh, M. (2016) Geological, Alteration and Mineralization Characteristics of Ali Javad Porphyry Cu-Au Deposit, Arasbaran Zone, NW Iran. Open Journal of Geology, 6, 859-874.

http://dx.doi.org/10.4236/ojg.2016.68066 
silver and tin content [1] Furthermore, they have valuable by-products such as Rhenium, Indium, platinum, palladium, selenium and tungsten [2].

Porphyry copper deposits can be considered as hydrothermal systems products during cooling temperature associated with shallow porphyry intrusions emplaced in magmatic arcs resulted from subduction [3]. Most of the porphyry deposits are related to Laramide and Neogene metallogenic events [4]. These deposits are large serves of medium to low grade metal content developed in shallow intrusive bodies with porphyry texture and associated volcanic equivalent rocks [5].

Large porphyry copper deposits were distributed in Iran, Pakistan, Armenia, and Turkey mainly between Arabian and Eurasian plate margins along Neo-Tethys oceanic crust subduction zone [6]. The subduction of oceanic crust in continental arc developed extensive magmatism which enjoyed several porphyry deposits in the subduction zone [6]. Iranian porphyry deposits were developed in four belts based on the geology and dating results of the deposits as following: 1) Arasbaran belt, 2) Middle part of Urumieh-Dokhtar belt, 3) Kerman belt, 4) Eastern Iran belt [7]. Arasbaran porphyry copper belt is located in northwestern Iran, bridging Eastern and Western parts of Alp-Himalayan mineralization belt. The belt extends from northwest into Azerbaijan Qarabagh mountain ranges which ultimately continue into Armenia and Turkey and host numerous porphyry copper deposits [7] [8].

Ali Javad Cu-Au porphyry deposit, which was explored in 2012 under the supervision of the first author, is located $20 \mathrm{~km}$ north of Ahar city in northwestern Iran (Figure 1). Sungun, Haft-Cheshmeh and Masjed-Daghi Cu-Mo porphyry deposits are located to the northwest while Mazraeh skarn and Sonajil porphyry copper deposits, the latter which is under exploration, are located to the east and south east of Ali Javad deposit, respectively [9]. The present study focuses mainly on geological, alteration and mineralization characteristics of Ali Javad deposit. We will compare characteristics of the deposit with proposed properties for porphyry copper deposits.

\section{Methodology}

Samples were selected from 32 exploratory drill cores with total length of 10,500 m for the purpose of petrographic and ore mineralographic studies as well as determination of alteration zones characteristics in Ali Javad $\mathrm{Cu}-\mathrm{Au}$ porphyry deposit (Figure 2). All the microscopic studies were conducted in Payam-e-Noor University, Tabriz branch, by Olympus BX51. Furthermore, 2600 samples were selected from different depths of logs for ICP analysis by ALS-Chemex laboratory in Spain. 3-D modeling of mineralization and alteration zones was made by Datamine software (http://www.dataminesoftware.com/).
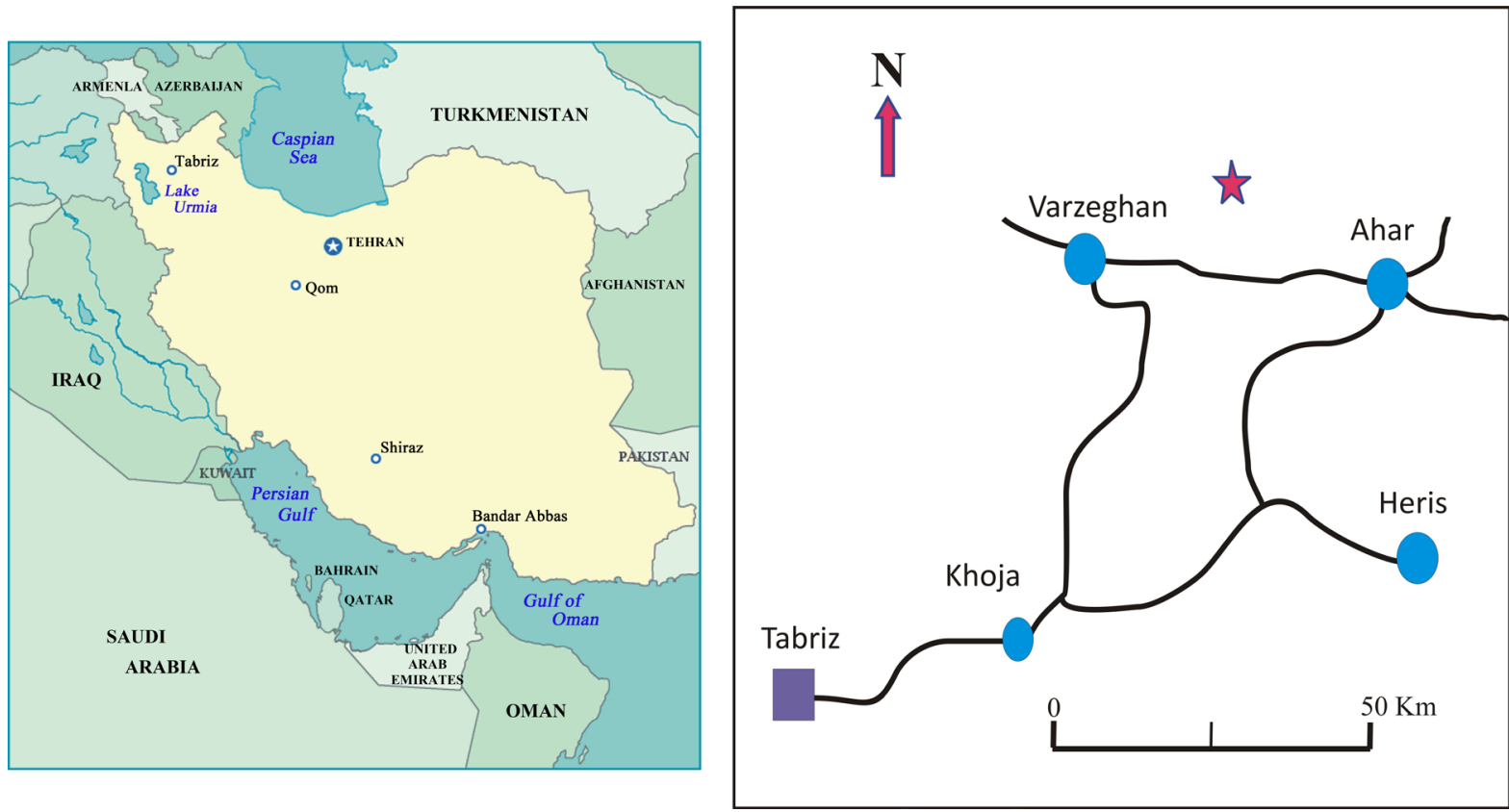

Figure 1. Geographic location and access road to the study area. The pink asterisk represents the location of Ali Javad deposit. 


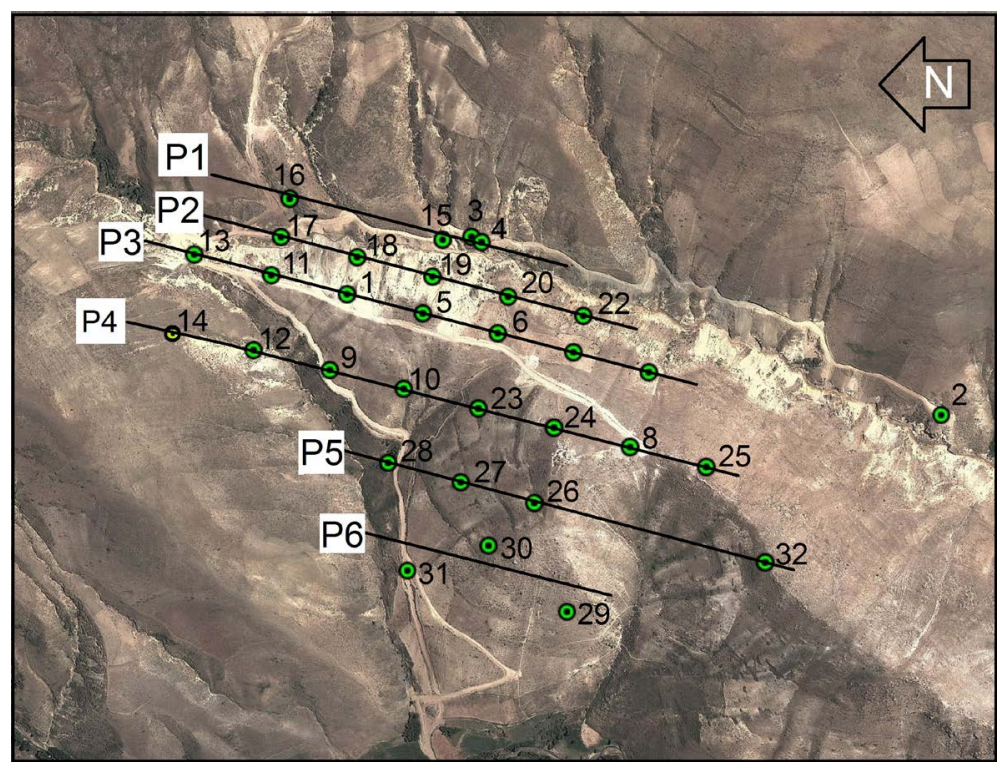

Figure 2. The location of exploratory boreholes in the studied Ali Javad deposit (background image is taken from https://www.google.com/earth/).

\section{Regional Geology}

The study area belongs to Central Iran Micro-continent [10] and western Alborz-Azerbaijan [11] based on the tectono-stratigraphic zones of Iran (Figure 3).

Arasbaran porphyry copper belt is situated in northwestern Iran, bridging eastern and western ends of AlpHimalayan metallogenic belt. The belt stretches into Qarabagh mountain ranges in Azerbaijan republic from the northwest which finally ends into Armenia and Turkey that host numerous porphyry copper deposits (Figure 4) [7] [8]. It continues from south and southeast into Central Iran metallogenic belt (Figure 3). Arasbaran Belt is considered as a 70 - $80 \mathrm{Km}$ wide and $400 \mathrm{Km}$ long belt which encompasses Cretaceous and Cenozoic volcanosedimentary deposits as well as Cenozoic intrusive bodies. Very small outcrops of Pre-Cambrian and Paleozoic formations, similar to Central Iran can be considered as evidences for similar geological history between these two areas. Generally speaking, the similarity may suggest a common geological history between Azerbaijan and Central Iran during these time lapses [10]. Cretaceous flysch and continental platform carbonates associated with mainly Cenozoic volcanic rocks covered older deposits in Arasbaran belt where magmatism began in Late Cretaceous and followed by extensive Cenozoic and Quaternary magmatic activities [12]-[14]. Upper Cretaceous and Paleocene calc-alkaline submarine volcanism mainly consisted of basic to acid volcanics as well as pyroclastic rocks [12]. Cenozoic to Quaternary volcanism consisted of two main stages of Eocene and Late Miocene-Quaternary volcanism. Volcanic rock sequences were mainly basic to intermediate Eocene rocks and shoshonitic in nature [15] which were in turn underlain by Late Miocene volcano-sedimentary sequences. Late Miocene-Quaternary rocks were characterized by an outcrop of basic to felsic rocks as well as related pyroclastics of calc-alkaline to shoshonitic and ultrapotassic nature [12] [16]. The last magmatic event in the area was characterized by isolated as well as fissure vent volcanoes such as Sabalan and Sahand that were mainly of shoshonitic and alkaline intra-plate nature [17] (Figure 4).

A wide variety of intrusive bodies of different nature and ages emplaced in the Arasbaran belt during Oligocene-Miocene [13] [14] [18]-[20]. Extensive alteration zones as well as various mineralization such as porphyry, skarn and epithermal deposits have been developed throughout the belt during emplacement of Oligocene-Miocene intrusions [12] [21] [22]. In Arasbaran belt, Plutonism initiated from middle to late Oligocene by calc-alkaline intrusion, followed by late Oligocene-lower Miocene shoshonitic intrusive bodies [14] [22]. Dacitic, granodioritic and monzonitic domes are the latest plutonic activity within the belt which cut through the earlier bodies. Shohsonitic intrusive bodies as well as younger domes are of adakitic nature while older intrusive bodies are of common calc-alkaline nature [14]. The formation of shoshonitic intrusions in the Arasbaran belt is attributed to partial melting of metasomatised lithospheric mantle in a post-collision tectonic setting [13] [14] 


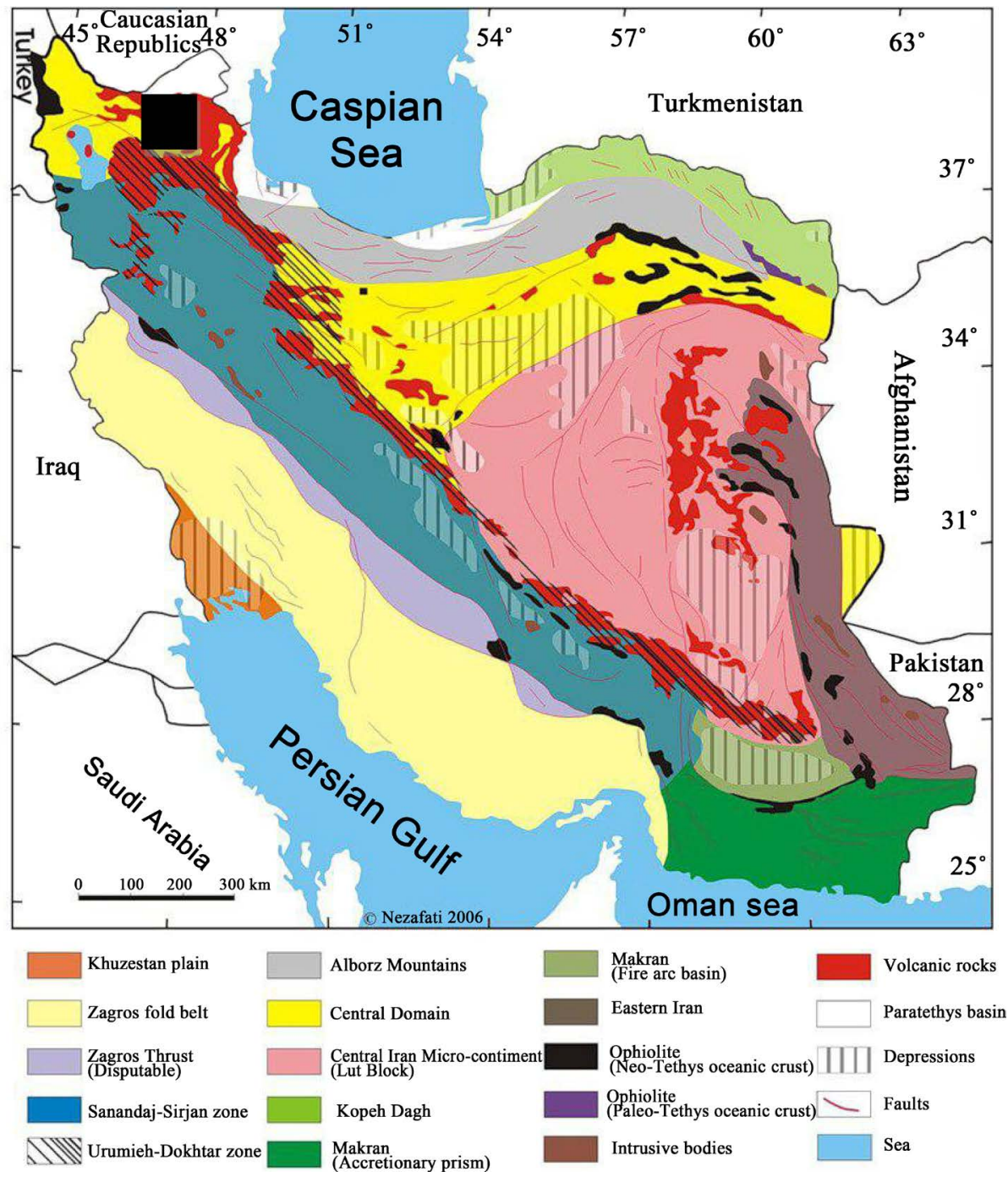

Figure 3. Tectono-stratigraphic zones of Iran and location of study area (black quadrangle) [10].

[22] while younger adakitic intrusions are attributed to slab roll-back and melting of the subsiding slab [19] and melting of lower mafic crust [7].

Porphyry copper mineralization in Arasbaran belt is essentially associated with Oligo-Miocene intrusive bodies. More than ten deposits and prospects for porphyry copper can be observed in the belt among which Sungun, Masjed-daghi, Haft-Cheshmeh, Sahebdivan, Niyaz, Miveh-Rud, Kighal and Ali Javad can be numerated (Figure 4) where Sungun is considered as a world class deposit [23]. Based on the dating results made on the belt, porphyry copper deposits formed during two stages: late Oligocene (28 - $27 \mathrm{Ma})$ and early Miocene (22 - $20 \mathrm{Ma})$ [7]. The formation of Ali Javad porphyry copper-gold deposit was attributed to younger plutonic activity in the area [9].

\section{Petrology and Petrography of Ali Javad Porphyry Intrusion}

Ali Javad porphyry stock which is located in the central part of the deposit is considered as the major agent to the hydrothermal alteration and mineralization in the area. The Ali Javad porphyry body which is $300 \times 500 \mathrm{~m}$ at the outcrop, has a porphyry texture with a strongly altered appearance. This makes it different from SheivarDagh granodioritic intrusion (Figure 5).

Based on the [24] proposed diagram, the composition of the intrusive rocks are dominantly quartz monzonite and few samples show quartz monzodiorite and granodioritic composition (Figure 6). Petrographically, the ma- 


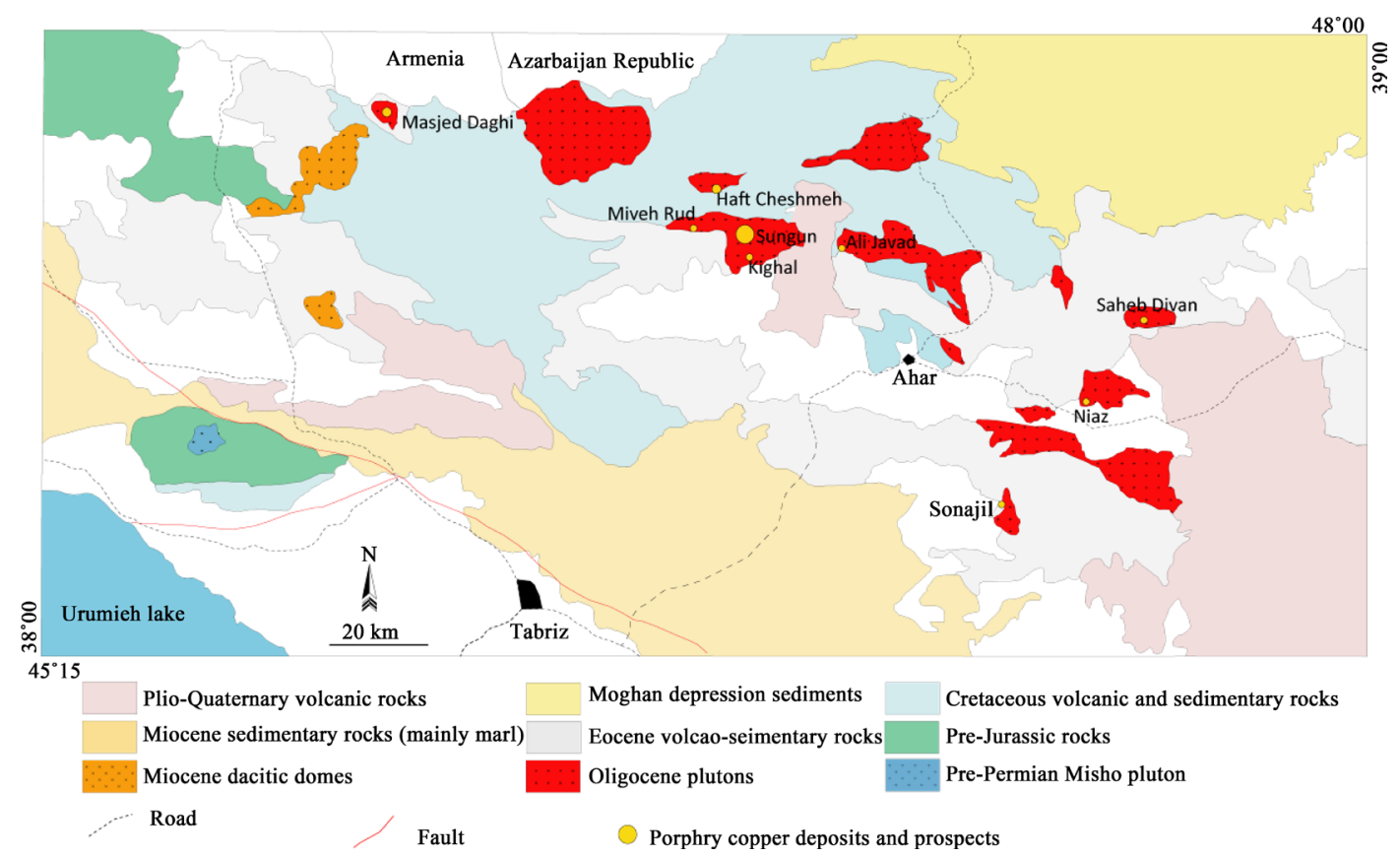

Figure 4. Geological map of Arasbaran belt and location of intrusive bodies as well as porphyry copper deposits [7].

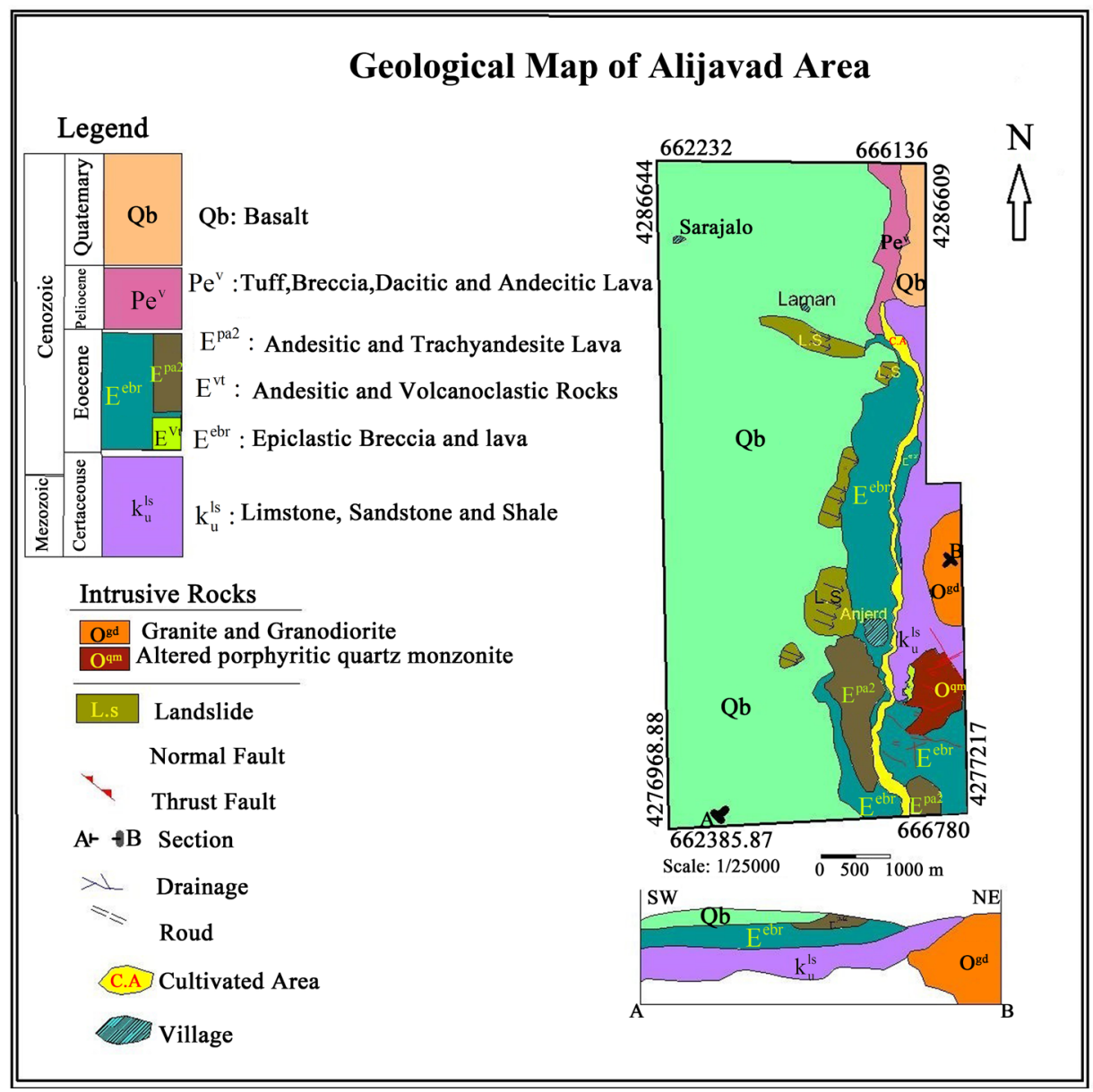

Figure 5. The geological map of the exploration area at the scale of 1:25,000 [9]. 


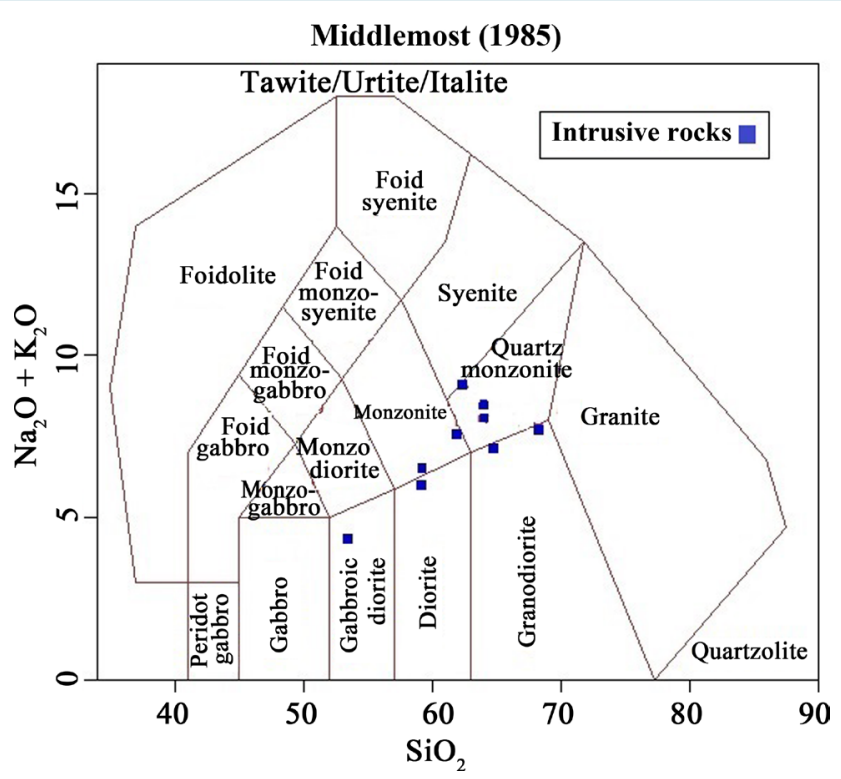

Figure 6. Ali Javad intrusive samples plotted on TAS diagram [24].
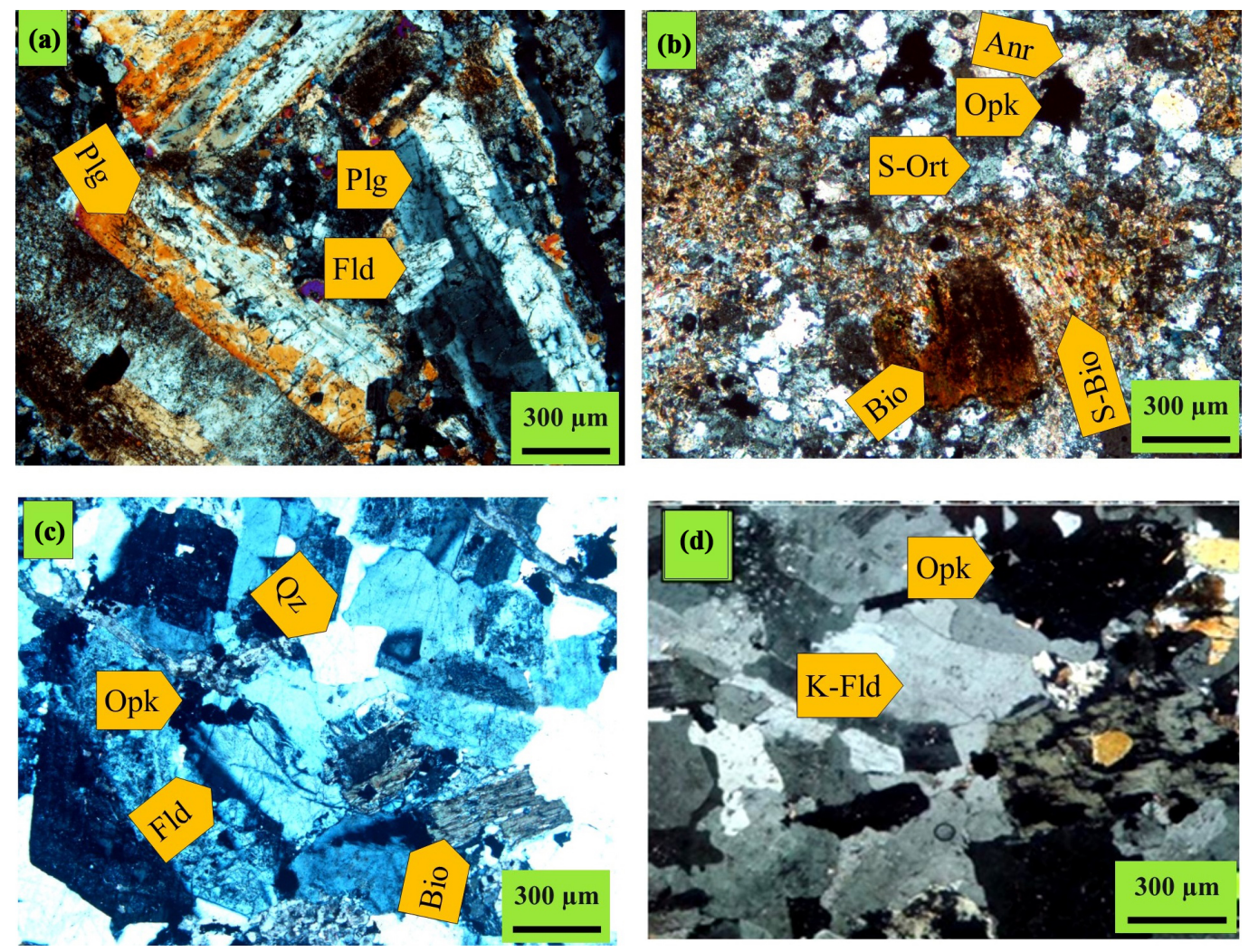

Figure 7. Microscopic images from Ali Javad porphyry intrusion: (a) Pheocrysts of plagioclase; (b) Secondary biotiteand Kfeldspar developed during potassic alterationin Ali Javad porphyry; (c) primary coarse-grained quartz in the porphyry quartz monzonite; (d) Primary alkali-feldspar (all pictures taken under XPL).

jor minerals consisted of plagioclase, alkali-feldspar and quartz associated with subordinate hornblende and primary biotite (Figure 7). During potassic, phyllic and argillic alteration, the primary minerals are replaced by secondary minerals. Plagioclases were mainly replaced by sericite, epidote, chlorite and calcite while mafic minerals were replaced by secondary biotite, magnetite and chlorite. Based on the [25], Ali Javad porphyry 
samples were plotted on shoshonitic and high-K calc-alkaline series rocks (Figure 8). Based on the [26] diagram, Ali Javad porphyry samples plotted on the volcanic arc granites field and post-collision granites (Figure 9).

\section{Alteration}

Alteration was defined as physical, chemical and mineralogical modification of the primary minerals [27]. Most of the important mineralization systems associated with intrusive granitoid bodies such as porphyry deposits and accompanying veins contain base and valuable metals are the result of hydrothermal fluids [1]. Recognition of associated alteration assemblages with each deposit types can be a valuable key to regional exploration and prospecting studies. The extent and intensity of alteration zones was directly proportional to the grade and tonnage of the deposit. Recognition of hydrothermal alteration assemblages was an important role in the determination of physical and chemical condition of hydrothermal fluids, evolution in mineralizing systems and hydrothermal deposit exploration [28]. Zoning in alteration assemblages which associates most porphyry type deposits consists of central potassic alteration core (secondary biotite + metasomatic K-feldspar) which turns outward into phyllic alteration (sericite + quartz), propylitic (epidote + chlorite + albite) and argillic which finally ends into unaltered rocks [29]. Zoning is observed both as progressive pattern where emanating fluids flushing off the central body and well represents temporal and spatial relationship from central part to periphery in some of deposits while in regressive pattern, outer zone minerals were developed on the central zone in some porphyry copper deposits containing base metal and precious metal veins, indicating cooling isothermal reverse into the system [30]. Potassic and propylitic alteration zones developed earlier than other alteration zones during system evolution [31]. However, in some porphyry deposits such as Butte in Montana, where light green sericitic and dark grey sericite-chlorite assemblages were simultaneous or even rather younger than central potassic alteration, propylitic alteration was developed farther [32]. In potassic alteration zone that near magmatic conditions prevails and primary constituent minerals turn unstable, hydrothermal alteration is the resultant of a fundamental

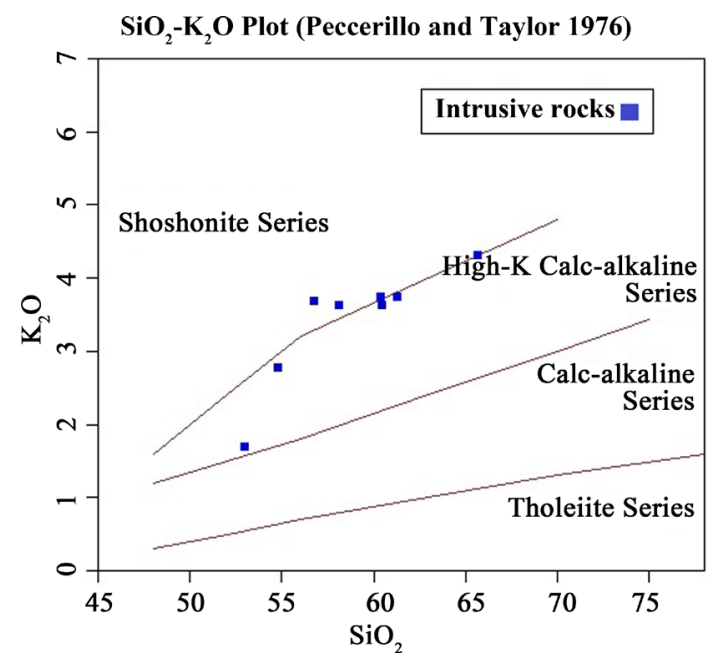

Figure 8. Ali Javad porphyry intrusion samples plotted on $\mathrm{K}_{2} \mathrm{O}-\mathrm{SiO}_{2}$ diagram [25].

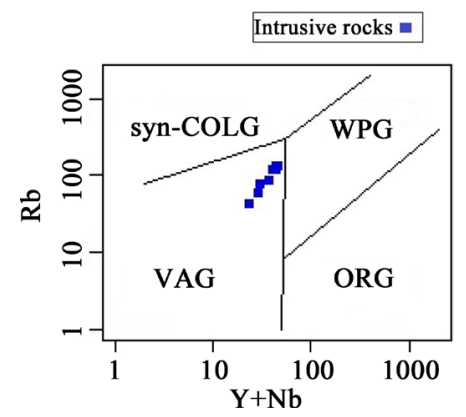

Figure 9. Ali Javad porphyry intrusion samples plotted on diagram [26]. 
hydrolysis process which comes out of high water/rock ratio while decreasing ratio leads to alteration intensity in weak hydrolysis process in propylitic zones [5].

\subsection{Alteration Types in Ali Javad Deposit}

Ali Javad porphyry stock of quartz monzonite composition is the cause to the development of hydrothermal alteration in Ali Javad district [9]. The alteration at the vicinity of the deep faults was of more intensity, especially along NE-SW trends. Ali Javad porphyry stockwork led to the intense alteration on the intrusive as well as country rock volcanic rocks which are mainly Eocene andesitic rocks (Figure 10, Figure 11). A variety of alteration zones including argillic, silicic, chloritic, propylitic, phyllic and potassic were observed in Ali Javad deposit which follow monzonitic Lowell \& Guilbert model. All alteration zones cropped out at the surface except potassic zone based on the surface alteration map (Figure 12).

Intermediate Argillic: the Alteration was observed in the southern and south eastern part of the area (Figure 12) [33]. The host rocks of the alteration are mainly Eocene volcanic rocks $\left(E^{\mathrm{vt}}\right)$ including porphyry andesite (Figure 13).

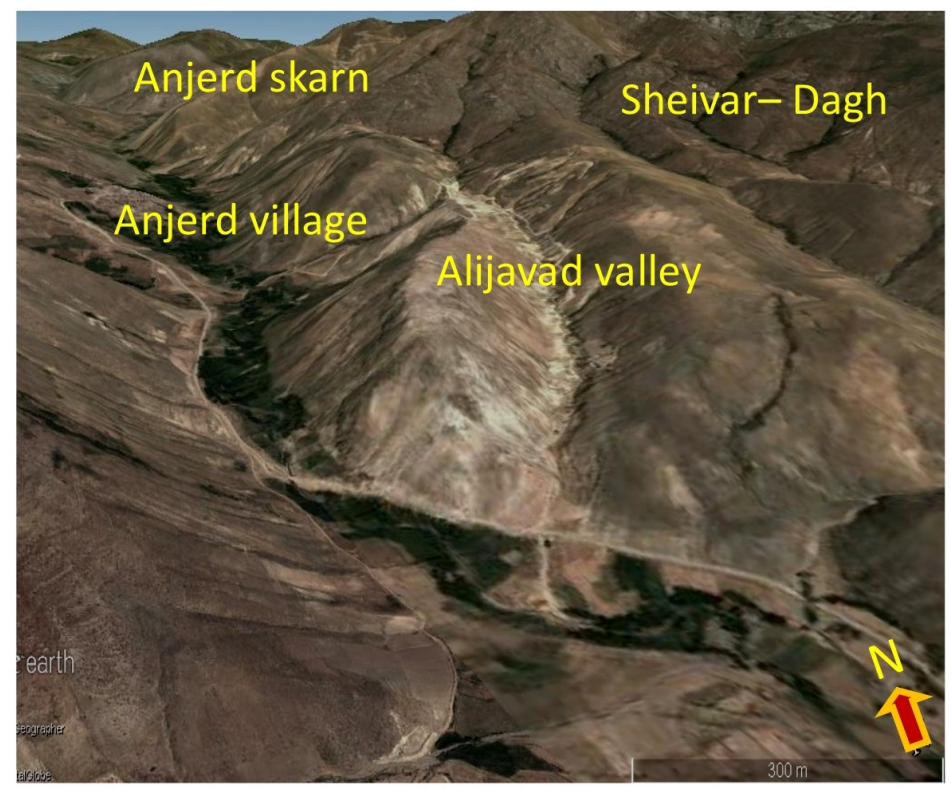

Figure 10. Development of alteration in Ali Javad deposit (background image is taken from https://www.google.com/earth).

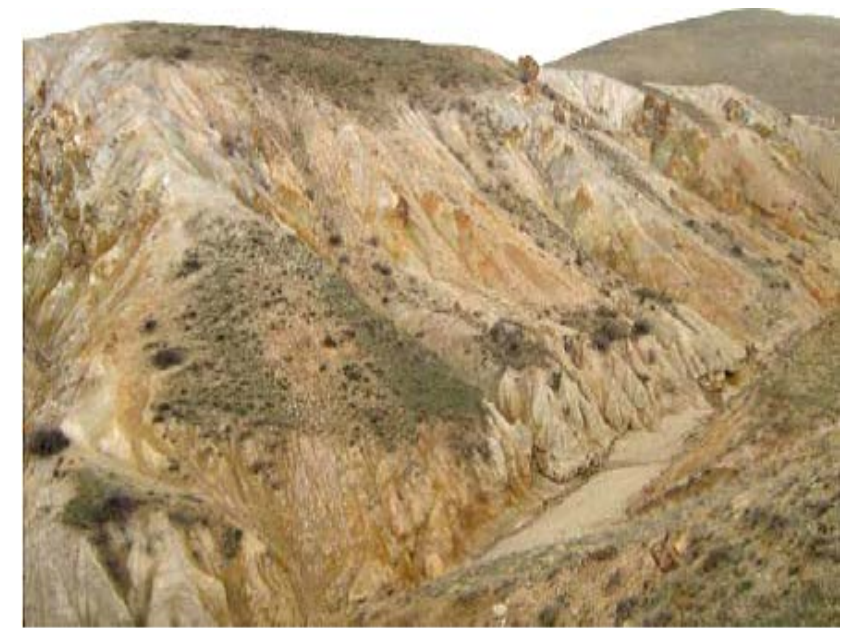

Figure 11. A general view of Ali Javad porphyry body with intensive alteration. 


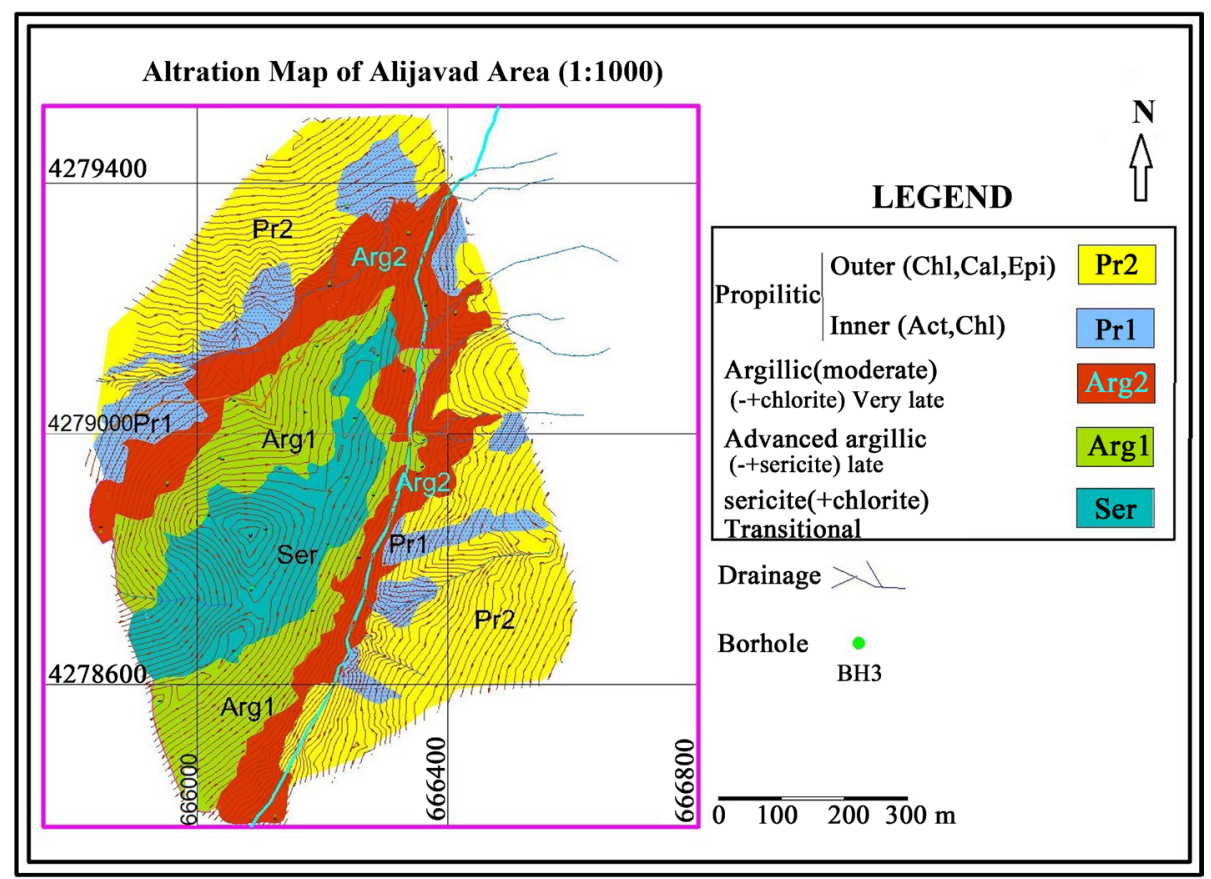

Figure 12. Alteration map of Ali Javad deposit with 1:1000 scale [9].

Advanced Argillic: the alteration was of considerable extent and intensity in Ali Javad district (Figure 12). It is noteworthy that dumortierite was also observed in the district which represents the upper parts of the porphyry systems and resembles to similar Cu-Mo-Au porphyry deposits in Canadian British Columbia [3].

Sericitic (Phyllic) alteration: the alteration at the central part of Ali Javad deposit was mainly in hypabysal quartz monzonite which was distinguished by Quartz, Sericite and pyrite (Figure 13(c)). This alteration zone hosted part of the mineralization in Ali Javad deposit.

Propylitic alteration: the alteration was observed at the periphery of Ali Javad district at farthest points on the eastern flank, near the village of Anjerd (Figure 12). Andesitic and trachy-andesitic lava well demonstrated propylitic alteration. The alteration in the intrusive rocks was distinguished by dominant development of epidote (Figure 13(d)).

Silicic alteration: The alteration was developed as silicic veins and veinlets,but sometimes as limited outcrops of silica cap at the central part of Ali Javad deposit. Silicic veinlets in porphyry quartz monzonite were also dominantly encountered in drill cores. The development of such silicic zones along the faults was especially associated with argillic alteration.

Potassic alteration: the zone is economically importance as part of the copper reserve is nested in it. The alteration did not crop out at the surface but was observed at the drill coresasneo formed biotite and secondary Kfeldspar in porphyry quartz monzonite (Figure 13(f)).

\subsection{3-D Modeling of Hydrothermal Alteration Zone}

3-D modeling of alteration zones in Ali Javad deposit was obtained from field studies and the study of 750 thins section from 32 core drills driven in the area [9]. The software utilized for the purpose was Datamine which provided 3-D subsurface alteration models shown in Figure 14. These zones demonstrated good match with Lowel and Guilbert model proposed for monzonitic typeporphyry deposits. Potassic alteration was located in the central and lower part of the deposit, above which phyllic alteration was observed that had sometimes outcrops on the surface. Advanced and intermediate argillic alteration had large extent in the central and upper parts of the deposit. Propylitic and chloritic alterations were observed in the western part of the deposit (Figure 14).

\section{Mineralization}

Ali Javad Cu-Au porphyry deposit was studied by microscopic studies on 420 polished sections, 2600 chemical 

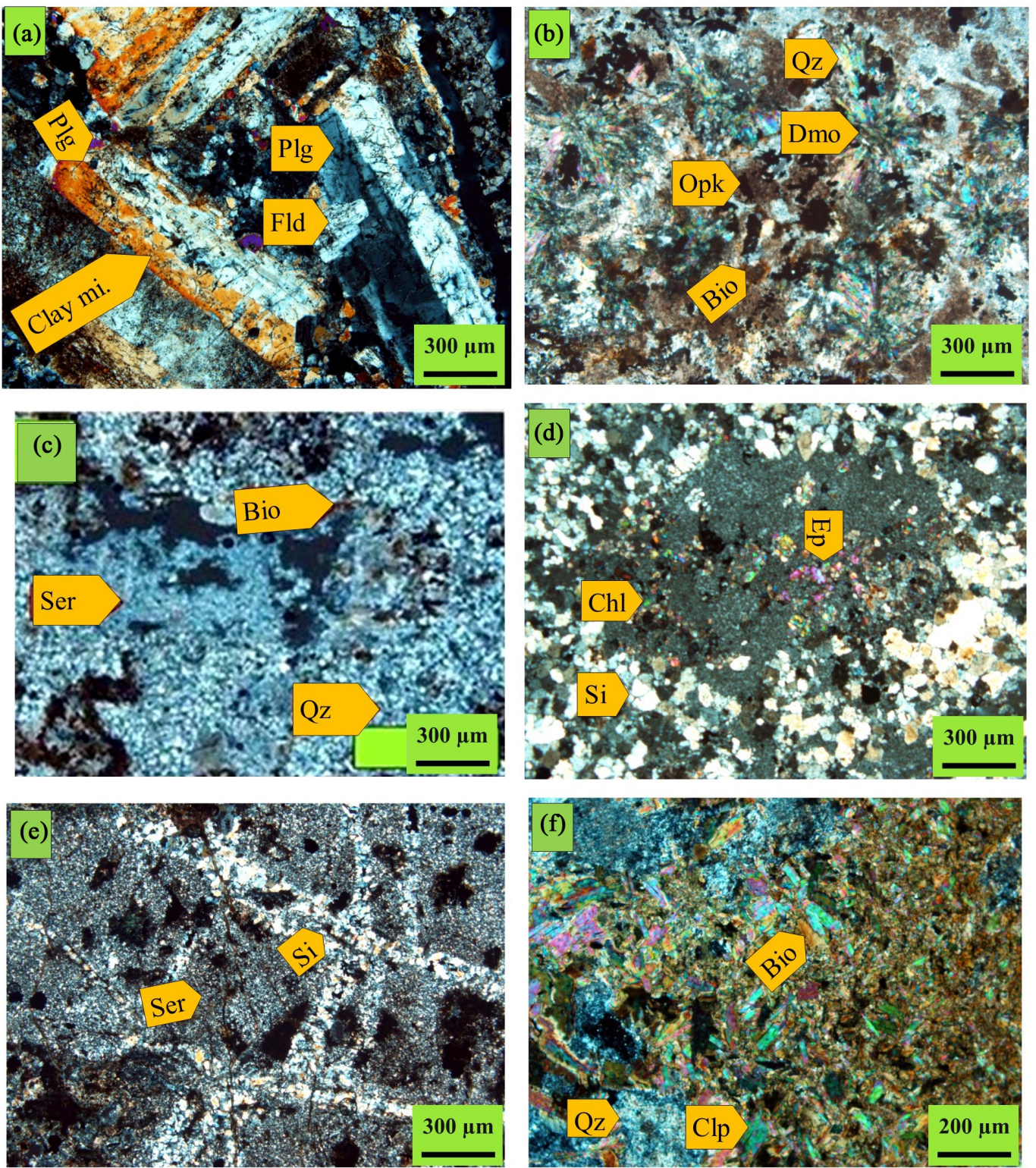

Figure 13. Microscopic images of alteration in thin sections: (a) intermediate argillic alteration; (b) advanced argillic alteration; (c) phyllic alteration that overprinted early potassic alteration; (d) propylitic alteration; (e) silicic alteration; (f) potassic alteration in the porphyry Ali Javad intrusion (all pictures taken under XPL).

analysis and Datamine software. These studies demonstrated that the mineralization was both as hypogene and supergene; hypogene mineralization occurred in the Ali Javad porphyry quartz monzonitic stock as well as altered Eocene andesite as disseminations, veins and veinlets. Based on the subsurface studies, leached zones, transitional zone, supergene zone and hypogene zone were observed in Ali Javad deposit. Most of the hypogene mineralization in the deposit occurred associated with potassic alteration [9].

\subsection{Mineralographic Studies}

Based on the mineralographic studies, hypogene mineralization occurred both in oxide and sulfide phases. The only oxide mineral was magnetite which was especially of more frequency in potassic alteration zone (Figure 15(a)). Sulfide ores developed in decreasing oxygen fugacity, increasing sulfur fugacity and decreasing temperature of ore fluids [9]. The most important sulfide mineral in the deposit was pyrite that developed earlier than 


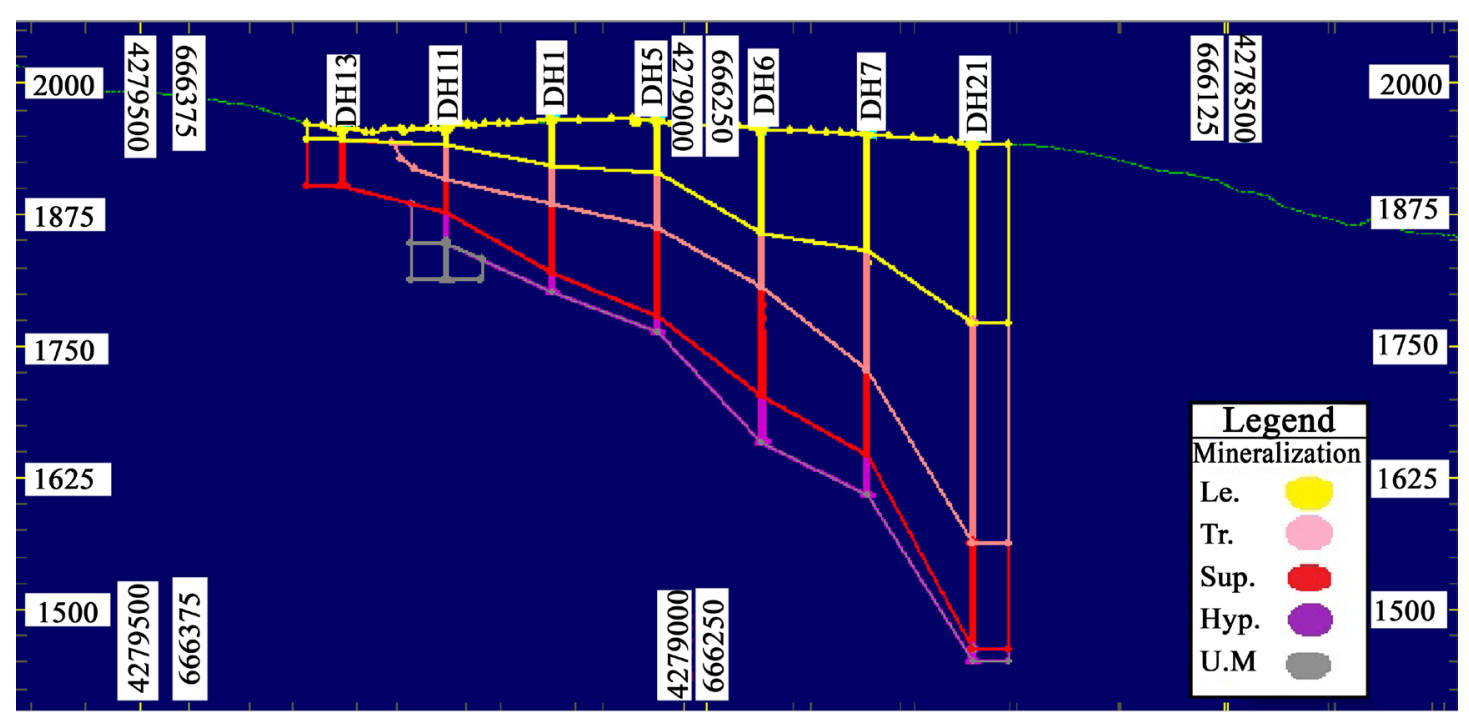

(a)

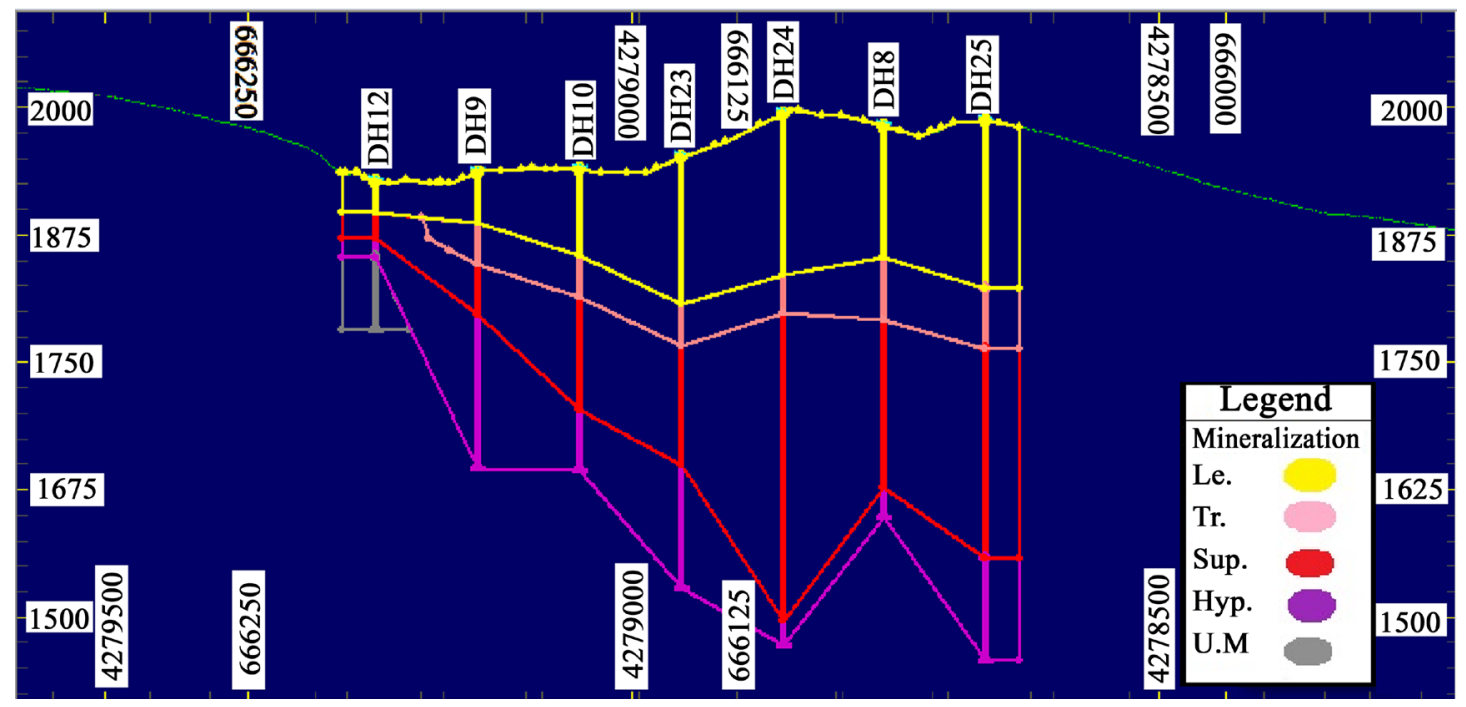

(b)

Figure 14. Views of the subsurface alteration profiles in the Ali Javad deposit prepared by Datamine software: (a) Profile 1 (b) Profile 2.

other sulfide minerals (Figure 15(c), Figure 15(d)). Chalcopyrite was the most abundant hypogene sulfide mineral after pyrite in Ali Javad deposit (Figure 15(b)) which was replaced by covellite and digenite in supergene zone [34]. Bornite was observed at the vicinity of chalcopyrite in hypogene and supergene zones, while minor molybdenite was observed in Ali Javad deposit (Figure 15(e)). Gold content of 1.8 ppm was obtained in the geochemical analysis results in spite of no visible gold in mineralographic studies, the content of which was proportional to magnetite content in potassic zone [9].

Supergene mineralization was observed extensively in Ali Javad deposit. Hematite, limonite and goethite were developed from magnetite and sulfide minerals replacement in leached zone during supergene processes (Figure 15(a), Figure 15(c) and Figure 15(d)). Specularite was sometimes observed in the samples which indicate hydrothermal alteration of magnetite (Figure 15(b)). Covellite and chalcocite were the most important sulfide minerals developed during supergene processes (Figure 15(d) and Figure 15(f)). This zone enjoyed minor bornite which developed between hypogene and supergene mineralization. At the shallow depth and in the supergene process, malachite and azurite minerals were also developed which were especially more obvious in the northern and northeastern parts of the deposit [9]. 

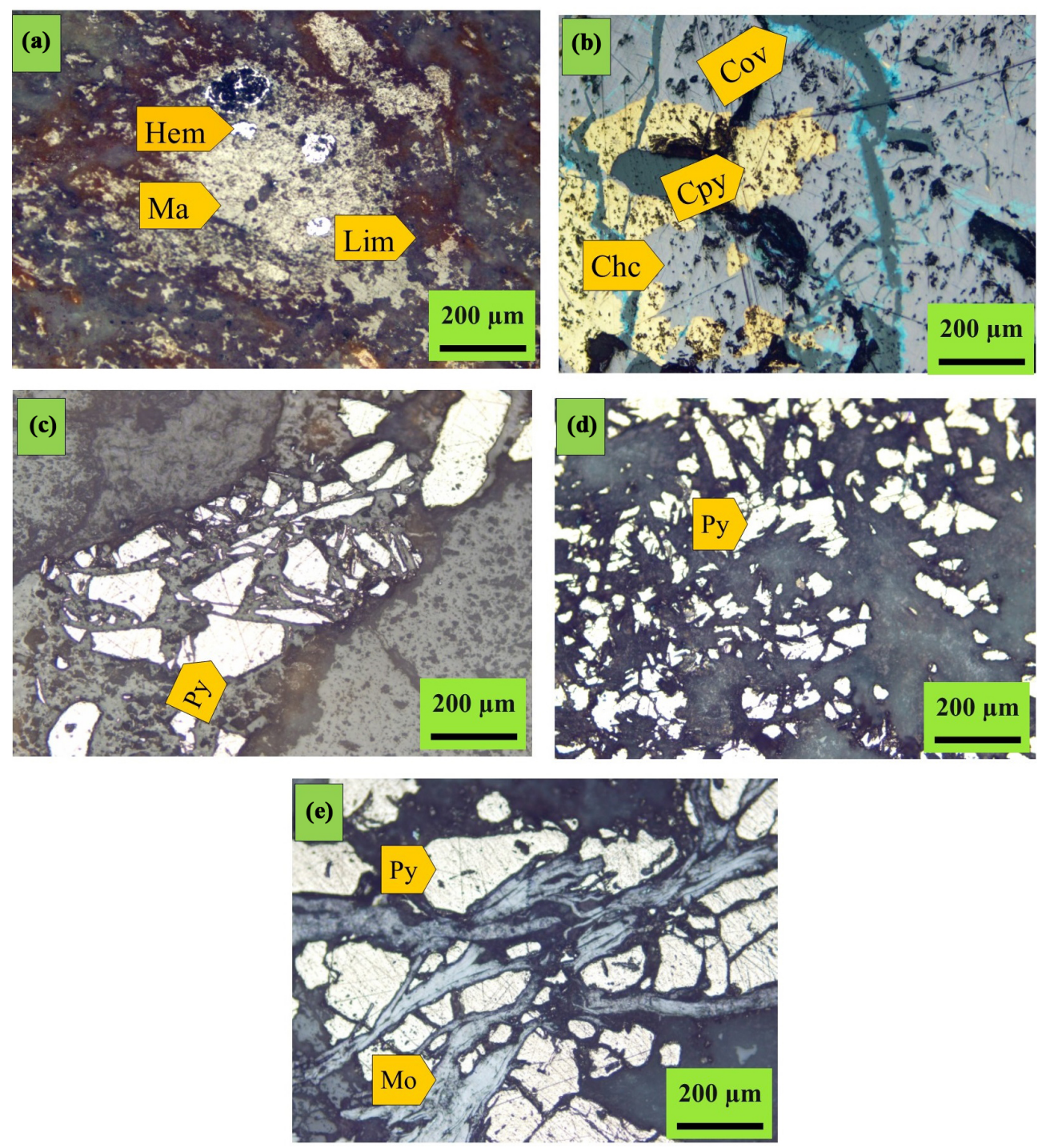

Figure 15. Microscopic photographs of polished sections in Ali Javad deposit: (a) magnetite is partially replaced by hematite leached zone; (b) association of chalcopyrite with covellite and chalcocite in the supergen zone; (c) brecciated pyrite leach zone; (d) granular pyrite leache zone; (e) fibrous molybdenite hypogen zone.

\subsection{Mineralization Zones}

Leached zone was developed at the uppermost part of the deposit which was characterized by hematite, limonite, goethite, pyrite and sometimes malachite. The thickness of the zone was variable and supergene zone was sometimes cropped out at the surface where weathering processes eroded leached and transitional zones (Figure 16) to the northern part of the deposit. The thickest part of the leached zone was in the central parts of the deposit with the thickness of $301 \mathrm{~m}$ at the core drills No. 21 and No. 25. The copper content in the zone is less than $0.2 \%$ [34]. The leached zone converted to the supergene zone through a transitional zone in between where covellite and chalcocite were also observed as well as pyrite, limonite and bornite [9]. The transitional zone was though roughly eroded in the northern part of the deposit with the maximum thickness of $140 \mathrm{~m}$ at the core drills No. 7 and No. 21 [34] and copper grades of $0.2 \%$ to $0.25 \%$ in the transitional zone beneath which supergene zone was located. The supergene zone cropped out at the northern part of the deposit at the core drills No. 17 and No. 18 which extends with the dip of 30 to 40 southwestward at depths (Figure 16). The minimum thickness of the supergene zone was $10 \mathrm{~m}$ located to the north of the deposit while the maximum thickness was located at the central part of the deposit at the core drills No. 18 and No. 24 with the maximum thickness of $180 \mathrm{~m}$. The average 


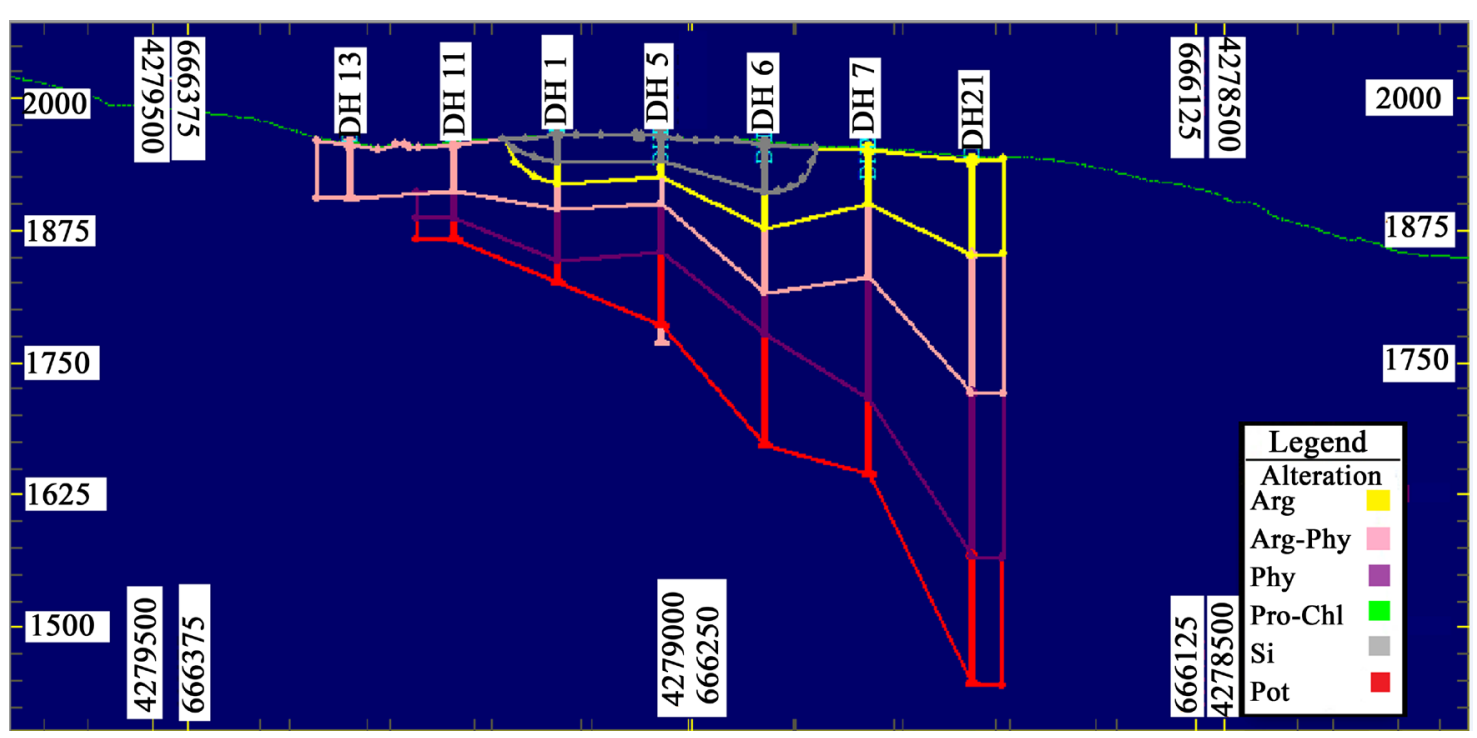

(a)

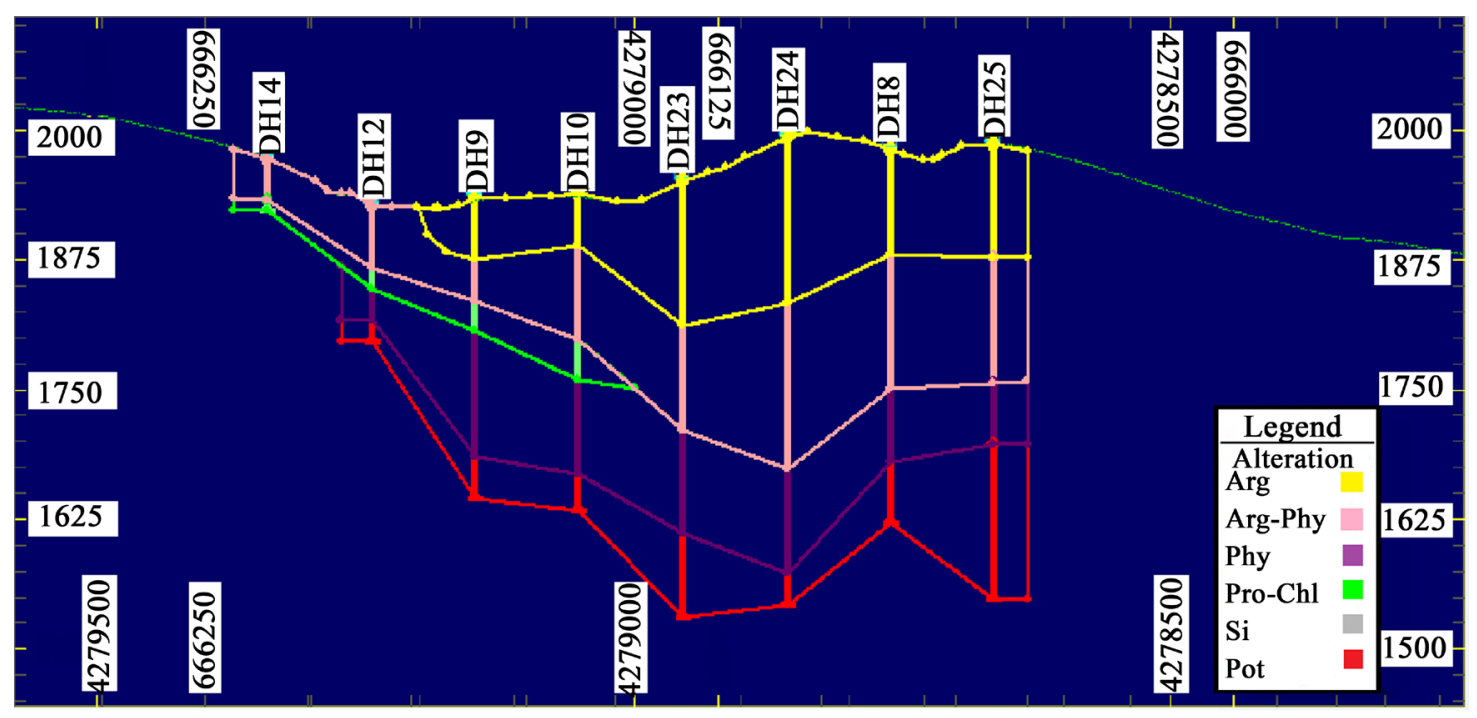

(b)

Figure 16. Cross sections of mineralization zones through Ali Javad deposit: (a) cross section No. 3; (b) cross section No. 4.

copper grade at this zone was $1.2 \%$ but copper grades of $2.5 \%$ were also observed.

Hypogene zone was the deepest mineralization zone which crossed in the northern part of the deposit at the core drills No. 11 and No. 17 from the depth of $50 \mathrm{~m}$. It dipped to the southern part of the deposit. The deepest hypogene mineralization was observed in core drills No. 21 and No. 24 which crossed at the depth of $475 \mathrm{~m}$. The average grade of copper was $0.3 \%-0.4 \%$ in the hypogene zone. The zone extended up to $650 \mathrm{~m}$ and probably more depth which has not been explored yet [9].

\subsection{3-D Modelling of Mineralization Zones and Reserve Evaluation}

The position and extent of the deposit and the situation of leached zone, transitional zone, supergene zone and hypogene zone to each other were shown in Figure 17 in both directions looking east and looking west. Leached zone and transitional zone were of small thickness in the eastern part of the deposit due to the erosion. This is the case for the supergene zone in the eastern part of the deposit while these zones were of more thickness in the central part of the deposit due to the dip of these zones with respect to the topographic dip. In the central part of the deposit, the total thickness of the leached and transitional zones exceeded $300 \mathrm{~m}$ where the supergene zone 

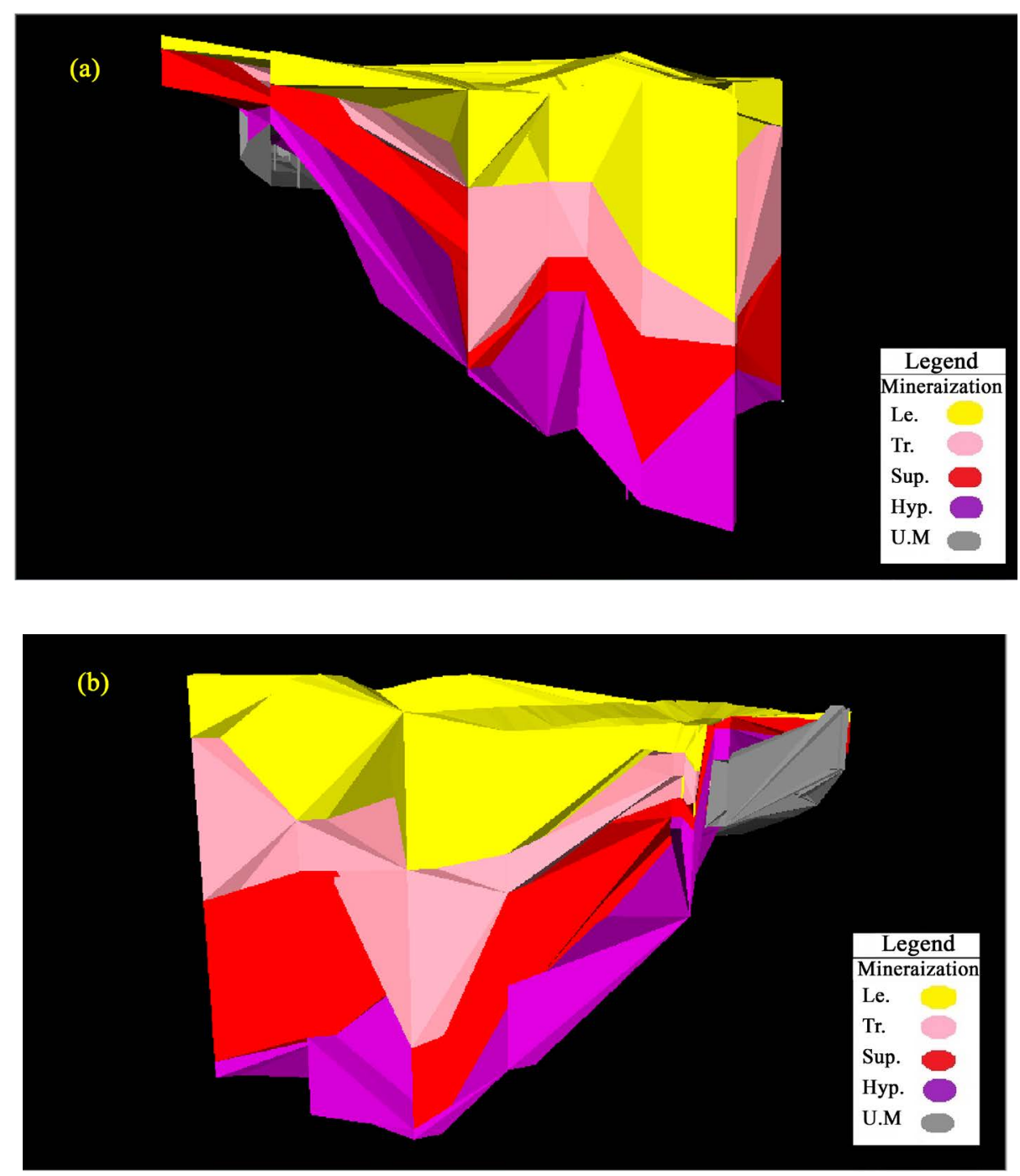

Figure 17. 3-D modelling ore zones of Ali Javad deposit associated modeled by Datamine software (a) looking west (b) looking east.

began from the depth of $270 \mathrm{~m}$. Sometimes, the thickness of the supergene zone amounted to $190 \mathrm{~m}$ in the central part of the deposit while hypogene zone began from the depth of $460 \mathrm{~m}$. Some boreholes did not get out of hypogene zone as the length of the deepest core drill in the Ali Javad deposit was $670 \mathrm{~m}$. The copper reserve was estimated 81.5 Mt@0.75\% Cu while gold reserve was estimated 37.8 Mt @1.86 ppm Au based on the krigging method applied to the data obtained [9].

\section{Conclusion}

Emplacement of quartz monzonitic porphyry stock at the Ali Javad area led to Cu-Au porphyry mineralization. The body is younger than Sheivar-Dagh granite-granodiorite body which experienced hydrothermal alteration. The Ali Javad porphyry body shows shoshonitic nature and has been emplaced in a post-collision tectonic setting. The intrusive body led to intermediate and advanced argillic, sericitic, silicic and potassic alteration within Eocene volcanic rocks and porphyry intrusive rocks. Potassic alteration was observed in drill core samples at depth, while argillic alteration developed more extensively at the surface which was similar to alteration zones of known model for porphyry copper deposits. Mineralization was as veins, veinlets and dissemination. Hypogene minerals included magnetite, chalcopyrite, pyrite, molybdenite and bornite. Leached zone, supergene zone and transitional zone between the two aforementioned zones as well as hypogene zone were evidently recog- 
nized in the deposit. The reserve was 81.5 Mt @ 0.75\% copper ore and 37.8 Mt 1.86 ppm gold ore.

\section{Acknowledgements}

The authors thank from the Mehr Asl Company for allowing sampling from the deposit and boreholes cores.

\section{References}

[1] Sillitoe, R.H. (2010) Porphyry Copper Systems. Economic Geology, 105, 3-41. http://econgeol.geoscienceworld.org/content/105/1/3 http://dx.doi.org/10.2113/gsecongeo.105.1.3

[2] Sinclair, W.D. (2007) Porphyry Deposits. In: Goodfellow, W.D., Ed., Mineral Deposits of Canada: A Synthesis of Major Deposit-Types, District Metallogeny, the Evolution of Geological Provinces, and Exploration Methods, Geological Association of Canada, Mineral Deposits Division, Special Publication, Canada, Newfoundland, 223-243.

[3] Beane, R.E. and Titley, S.R. (1981) Porphyry Copper Deposits: Part II. Hydrothermal Alteration and Mineralization. Society of Economic Geologists, USA, Vol. 75, 235-269.

[4] Cooke, D.R., Hollings, P. and Walsh, J.L. (2005) Giant Porphyry Deposits: Characteristics, Distribution, and Tectonic Controls. Economic Geology, 100, 801-818. http://econgeol.geoscienceworld.org/content/100/5/801 http://dx.doi.org/10.2113/gsecongeo.100.5.801

[5] Barnes, H.L. (1997) Geochemistry of Hydrothermal Ore Deposits. 3rd Edition, John Wiley Publications, New York.

[6] Richards, J.P. (2014) Tectonic, Magmatic, and Metallogenic Evolution of the Tethyan Orogen: From Subduction to Collision. Ore Geology Reviews, 70, 323-345. http://www.sciencedirect.com/science/article/pii/S0169136814003369 http://dx.doi.org/10.1016/j.oregeorev.2014.11.009

[7] Aghazadeh, M., Hou, Z., Badrzadeh, Z. and Zhou, L. (2015) Temporal-Spatial Distribution and Tectonic Setting of Porphyry Copper Deposits in Iran: Constraints from Zircon U-Pb and Molybdenite Re-Os Geochronology. Ore Geology Reviews, 70, 385-406. http://www.sciencedirect.com/science/article/pii/S0169136815000694 http://dx.doi.org/10.1016/j.oregeorev.2015.03.003

[8] Moritz, R., Rezeau, H., Ovtcharova, H., Tayan, R., Melkonyan, R., Hovakimyan, S., Ramazanov, V., Selby, D., Ulianov, A., Chiaradia, M. and Putlitz, B. (2015) Long-Lived, Stationary Magmatism and Pulsed Porphyry Systems during Tethyan Subduction to Post-Collision Evolution in the Southernmost Lesser Caucasus, Armenia and Nakhitchevan. Gondwana Research, in Press. http://www.sciencedirect.com/science/article/pii/S1342937X15002555 http://dx.doi.org/10.1016/j.gr.2015.10.009

[9] Hajalilou, B. (2012) Final Report of Exploration in Ali Javad Area, Ministry of Industry, Mine and Trading, Mehr Asl Company. (In Persian)

[10] Aghanabati, A. (2006) Geology of Iran. Geological Survey of Iran. (In Persian)

[11] Eftekhar Nejad, J. (1980) Tectonic Classification of Iran in Relation to Depositional Basins. Journal of Iranian Petroleum Society, 82, 19-28. (In Persian)

[12] Aghazadeh, M. (2009) Petrology and Geochemistry of Anzan, Khankandi and Sheivar Dagh granitoids (North and East of Ahar, Eastern Azerbaijan) with References to Associated Mineralization. Unpublished PhD Thesis, Tarbiat Modares University, Tehran, Iran. (In Persian)

[13] Aghazadeh, M., Castro, A., Omran, N.R., Emami, M.H., Moinvaziri, H. and Badrzadeh, Z. (2010) The Gabbro (Shoshonitic)-Monzonite-Granodiorite Association of Khankandi Pluton, Alborz Mountains, NW Iran. Journal of Asian Earth Sciences, 38, 199-219. http://www.sciencedirect.com/science/article/pii/S1367912010000179 http://dx.doi.org/10.1016/j.jseaes.2010.01.002

[14] Aghazadeh, M., Castro, A., Badrzadeh, Z. and Vogt, K. (2011) Post-Collisional Polycyclic Plutonism from the Zagros Hinterland: The Sheivar Dagh Plutonic Complex, Alborz Belt, Iran. Geological Magazine, 148, 980-1008. http://journals.cambridge.org/action/displayAbstract?fromPage $=$ online\&aid $=8348253 \&$ fileId $=$ S0016756811000380 http://dx.doi.org/10.1017/S0016756811000380

[15] Dilek, Y., Imamverdiyev, N. and Altunkaynak, S. (2010) Geochemistry and Tectonics of Cenozoic Volcanismin the Lesser Caucasus (Azerbaijan) and the Peri-Arabian Region: Collision Induced Mantle Dynamics and Its Magmatic Fingerprint. International Geology Reviews, 52, 536-578. http://dx.doi.org/10.1080/00206810903360422 http://www.tandfonline.com/doi/abs/10.1080/00206810903360422

[16] Ahmadzadeh, G., Jahangiri, A., Lentz, D. and Mojtahedi, M. (2010) Petrogenesis of Plio-Quaternary Post-Collisional Ultrapotassic Volcanism in NW of Marand, NW Iran. Journal of Asian Earth Sciences, 39, 37-50.

http://www.sciencedirect.com/science/article/pii/S1367912010000623 http://dx.doi.org/10.1016/j.jseaes.2010.02.008 
[17] Kheirkhah, M., Allen, M.B. and Emami, M. (2009) Quaternary Syn-Collision Magmatism from the Iran/Turkey Borderlands. Journal of Volcanology and Geothermal. Research, 182, 1-12. http://dx.doi.org/10.1016/j.jvolgeores.2009.01.026

[18] Babakhani, A.R., Lesquyer, J.L. and Rico, R. (1990) Geological Map of Ahar Quadrangle. Geological Survey of Iran, Tehran, Iran. (Scale 1:250,000)

[19] Jahangiri, A. (2007) Post-Collisional Miocene Adakitic Volcanism in NW Iran: Geochemical and Geodynamic Implications. Journal of Asian Earth Sciences, 30, 433-447. http://dx.doi.org/10.1016/j.jseaes.2006.11.008 http://www.sciencedirect.com/science/article/pii/S1367912007000120

[20] Castro, A., Aghazadeh, M., Badrzadeh, Z. and Chichorro, M. (2013) Late Eocene-Oligocene Post-Collisional Monzonitic Intrusions from the Alborz Magmatic Belt, NW Iran. An Example of Monzonite Magma Generation from a Metasomatized Mantle Source. Lithos, 180-181, 109-127. http://dx.doi.org/10.1016/j.lithos.2013.08.003 http://www.sciencedirect.com/science/article/pii/S0024493713002417

[21] Mehrpartou, M. (1993) Contributions to the Geology, Geochemistry, Ore Genesis and Fluid Inclusion Investigations on Sungun Cu-Mo Porphyry Deposit, (North-West of Iran). PhD Thesis, Hamburg University, Hamburg, Germany.

[22] Jamali, H., Dilek, Y., Daliran, F., Yaghubpur, A. and Mehrabi, B. (2009) Metallogeny and Tectonic Evolution of the Cenozoic Ahar-Arasbaran Volcanic Belt, Northern Iran. International Geology Reviews, 52, 608-630. http://www.tandfonline.com/doi/abs/10.1080/00206810903416323?journalCode=tigr20 http://dx.doi.org/10.1080/00206810903416323

[23] Shafiei, B., Haschke, M. and Shahabpour, J. (2009) Recycling of Orogenic Arc Crust Triggers Porphyry Cu Mineralization in Kerman Cenozoic Arc Rocks, Southeastern Iran. Mineralium Deposita, 44, 265-283. http://link.springer.com/article/10.1007\%2Fs00126-008-0216-0 http://dx.doi.org/10.1007/s00126-008-0216-0

[24] Middlemost, E.A.K. (1985) Magmas and Magmatic Rocks. Longman, London.

[25] Peccerillo, A. and Taylor, S.R. (1976) Geochemistry of Eocene Calc-Alkaline Volcanic Rocks from the Kastamonu Area, Northern Turkey. Contributions to Mineralogy and Petrology, 58, 63-81. http://dx.doi.org/10.1007/BF00384745 http://link.springer.com/article/10.1007/BF00384745\#page-1

[26] Pearce, J.A. (1984) Trace Element Characteristics of Lavas from Destructive Plateundaries. In: Thrope, R.I., Ed., Andesites: Orogenic Andesites and Related Rocks, Wiley, Chichester, 525-548.

[27] Bates, R.L. and Jackson, J.A. (1980) Glassary of Geology. 2nd Edition, American Geological Institute, Virginia.

[28] Johnson, D.A. and Barton, M.D. (2000) Time-Space Development of an External Brine-Dominated, Igneous-Driven Hydrothermal System: Humboldt Mafic Complex, Western Nevada, Part I. In: Dilles, J.H., Barton, M.D., Johnson, D.A., Proffett, J.M. and Einaudi, M.T., Eds., Contrasting Styles of Intrusion-Associated Hydrothermal Systems: Guidebook Series, Vol. 32, Society of Economic Geologists, 127-144.

[29] Lowell, J.D. and Guilbert, J.M. (1970) Lateral and Vertical Alteration-Mineralization Zoning in Porphyry Ore Deposits. Economic Geology, 65, 373-408. http://economicgeology.org/content/65/4/373.full.pdf http://dx.doi.org/10.2113/gsecongeo.65.4.373

[30] Hajalilou, B. (2011) Fluid Inclusion Geothermometery. Payame-Noor University Press, Tabriz. (In Persian)

[31] McMillan, P.F. (1994) Water Solubility and Speciation Models. In: Carroll, M.R. and Holloway, J.R., Eds, Volatiles in Magmas, Vol. 30, Mineralogical Society of America, 131-156.

[32] Field, C.W., Zhang, L., Dilles, J.H., Rye, R.O. and Reed, M.H. (2005) Sulfur and Oxygen Pre-Main Stage Porphyry $\mathrm{Cu}-\mathrm{Mo}$ and Late Shallow Main Stage Base Mineral Deposits, Butte District, Montana. Chemical Geology, 215, 61-93. http://www.sciencedirect.com/science/article/pii/S0009254104004061 http://dx.doi.org/10.1016/j.chemgeo.2004.06.049

[33] Dastar, S. (2014) Investigation of Alteration Zones in Ali Javad Porphyry Copper Deposit. Payame-Noor University, Tabriz. (In Persian)

[34] Ansari, S. (2014) Investigation of Mineralization Zones in Ali Javad Porphyry Copper Deposit. Payame-Noor University, Tabriz. (In Persian) 


\section{Submit or recommend next manuscript to SCIRP and we will provide best service for you:}

Accepting pre-submission inquiries through Email, Facebook, LinkedIn, Twitter, etc.

A wide selection of journals (inclusive of 9 subjects, more than 200 journals)

Providing 24-hour high-quality service

User-friendly online submission system

Fair and swift peer-review system

Efficient typesetting and proofreading procedure

Display of the result of downloads and visits, as well as the number of cited articles

Maximum dissemination of your research work

Submit your manuscript at: http://papersubmission.scirp.org/ 